Makai, P., Klazinga, N., Wagner, C., Boncz, I., Gulácsi, L. Quality management and patient safety: survey results from 102 Hungarian hospitals. Health Policy: 2009, 90(2-3), 175-180

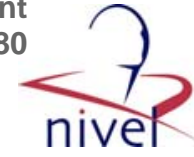

\begin{tabular}{|l|l|}
\hline Postprint Version & 1.0 \\
\hline Journal website & $\underline{\text { http://dx.doi.org/10.1016/j.healthpol.2008.09.009 }}$ \\
\hline Pubmed link & $\underline{\text { http://www.ncbi.nlm.nih.gov/pubmed/19004518 }}$ \\
\hline DOI & $10.1016 / \mathrm{j}$. healthpol.2008.09.009 \\
\hline
\end{tabular}

\title{
Quality management and patient safety: Survey results from 102 Hungarian hospitals
}

\author{
PETER MAKAI ${ }^{\mathrm{a}}$, NIEK KLAZINGA ${ }^{\mathrm{c}}$, CORDULA WAGNER ${ }^{\mathrm{e}}$, IMRE BONCZ ${ }^{\mathrm{b}}$ AND LÁSZlO \\ GULACSI $^{\mathrm{d}}$ \\ ${ }^{a}$ Institute of Health Policy and Management, Erasmus University of Rotterdam, P.O. Box \\ 1738, 3000DR Rotterdam, The Netherlands \\ ${ }^{b}$ Department of Health Economics, Policy, and Management, University of Pécs, Hungary \\ ${ }^{\mathrm{C}}$ Department of Social Medicine, Academic Medical Centre, University of Amsterdam, The \\ Netherlands \\ ${ }^{\mathrm{d}}$ Health Economics and Technology Assessment Research Centre, Corvinus University of \\ Budapest, Hungary \\ ${ }^{\mathrm{e}}$ Netherlands Institute for Health Services Research, The Netherlands
}

\begin{abstract}
Objectives: The aim of this study is to describe the development of quality management systems in Hungarian hospitals. It also aims to answer the policy question, whether a separate patient safety policy should be created additional to quality policies, on national as well as hospital level.

Method: In 2005, a questionnaire survey was conducted to evaluate the existing quality management systems in all Hungarian hospitals. The relationship between the level of the development of quality management systems, the certification status and the current level of patient safety activities was investigated using linear regression. Quality was measured with the quality management system development score (QMSDS), and patient safety by the number of patient safety activities.

Results: 102 of 134 (76\%) of the hospitals have returned the questionnaire. The average hospital has 24.5 of 35 core quality activities, and 4 of 11 patient safety activities. There is a statistically significant but weak relationship between the QMSDS and the number of patient safety activities, explaining $12 \%$ of the latter's variance. Certification (International Standards Organisation (ISO) and professional standard based) is not significantly related to patient safety.

Conclusions: In our study quality by QMSDS is weakly related; however, certification is not significantly related to patient safety. We conclude that separate patient safety policies seem worthwhile to be created for the hospital sector in addition to the ongoing quality improvement efforts in Hungary.
\end{abstract}


Makai, P., Klazinga, N., Wagner, C., Boncz, I., Gulácsi, L. Quality management and patient safety: survey results from 102 Hungarian hospitals. Health Policy: 2009, 90(2-3), 175-180

\section{BACKGROUND}

Quality improvement has become an important issue during the past decades, with a number of countries aiming for high quality and safe healthcare [1]. In the domain of quality, patient safety has become of particular interest [2] and [3]. According to several studies, [4], [5], [6], [7], [8], [9], [10] and [11], between $2.9 \%$ and $16.6 \%$ of patients are harmed by the inappropriate healthcare treatment. As a result, several countries have adopted specific patient safety policies [12] and the OECD has developed a set of patient safety indicators on the health system level [13]. The main aim of patient safety efforts is to eliminate adverse events. According to literature, most adverse events have been caused by system error [2] and [14]. Likewise, hospitals have adopted patient safety activities, like adverse event reporting systems [15], and risk management [16].

A more traditional way of dealing with quality of care was through the internal quality management systems (QMSs) of the hospitals, and through external evaluation (certification, accreditation, visitation or quality-award-based activities) [17]. Quality management systems are defined as 'all processes that were explicitly designed to monitor, assess and improve the quality of care' [18]. Quality management systems have been implemented in diverse healthcare systems [17], [19], [20], [21] and [22]..

Some authors claim that although patient safety is a part of quality, its approach is different from previous quality management efforts [23], [24] and [25]. Patient safety was more concerned with uncovering the causes of incidents, and removing these causes, then with the traditional quality perspective of emphasising the spread of effective quality interventions. However, the differences between the two approaches have become smaller. Therefore, according to the same authors [23], [24] and [25] patient safety should be integrated into the existing quality improvement efforts.

Quality improvement activities and quality management systems have become widespread in Hungary as well. The Hungarian hospital system consists of 134 hospitals. Hospital care is hierarchically structured into city hospitals, treating the simplest cases, large county hospitals (1000-1600 beds) and Budapest hospitals with multiple specialties. University and national specialty hospitals treat the most severe cases. In addition, there are also other types of specialty hospitals, and children's hospitals. The main policy actors are the Ministry of Health $(\mathrm{MoH})$ with a regulatory function, the National Public Health and Medical Officer's Service (NPHMOS) with quality control responsibility, and the National Health Insurance Fund Administration (NIHFA). Hospitals are financed by a Hungarian version of the US Diagnostic Related Group (DRG) system.

Quality management activities first started with the BIOMED projects funded by the European Commission in the early 90s [26] and [27]. By 1997, the operation of quality management systems became obligatory by law, without detailed specification [28]. QMS was implemented without a clearly defined government quality policy, and its effects have never been evaluated. To date, our survey is one of the first systematic efforts to monitor the QMS in Hungary.

In the late 1990s, the ISO (International Standards Organisation) certification scheme received support from the $\mathrm{MoH}$ and the ISO healthcare manual was created. In 2001, the Hungarian Hospital Care Standards (HHCS) were developed, together with a manual, based on the Joint Commission International's Hospital Standards) [29]. Although originally intended as basis for accreditation, the accreditation scheme based on HHCS has not been implemented. In practice, the HHCS is used in the certification process of hospitals. In 2002 a guideline was issued on the requirements of the internal QMS [30], based on ISO and HHCS. In addition, a series of clinical guidelines were issued by the MoH [31]. Externally, a set of minimum standards are controlled by the NPHMOS through inspection and licensing of healthcare organizations. The effects of implementation are described elsewhere [21].

Recently patient safety became an important issue after media coverage on fatal medical errors. QMS has been implemented in Hungary for several years, and patient safety and related activities may have resulted from these systems [22]. There is no patient safety policy 
Makai, P., Klazinga, N., Wagner, C., Boncz, I., Gulácsi, L. Quality management and patient safety: survey results from 102 Hungarian hospitals. Health Policy: 2009, 90(2-3), 175-180

as such, but there are certain patient safety-related activities for instance, obligatory drug committees, infection committees and a patient identification system, in order to reduce wrong patient/wrong site surgery [31]. This raises an important policy question; do patient safety activities actually derive from current quality management systems, or is patient safety a separate managerial activity requiring a separate policy?

First, our study aims to describe the status of QMS of the Hungarian hospitals, and the existing patient safety activities. The second aim is to investigate the relationship between the number of patient safety activities in the hospitals, and the development level of the quality management system and external certification (ISO and HHCS) of the hospitals. Based on the above, the third aim is to answer the policy question, whether a separate patient safety policy should be created additional to the quality policy, or can patient safety be expected to emerge from the existing QMS.

\section{METHODS}

\subsection{Study design}

In January of 2005, Hungarian hospitals were surveyed on the implementation of QMS inside the hospitals. The questionnaire also included questions on patient safety activities. The survey was a part of the European Research Network on Quality Management in Healthcare (ENQuaL) project, carried out by the Corvinus University Budapest in Hungary. The questionnaire was translated, and the $\mathrm{MoH}$ distributed the questionnaire to all 134 hospitals in the country. The questionnaires focused on the hospital-level quality management system and quality managers filled out the questionnaires.

\subsection{ENQuaL questionnaire and analysis}

The questionnaire consisted of the following main parts: (1) policy and strategy documents; (2) human resource management; (3) protocols and processes; (4) elements of the quality management system; (5) analysis of process and outcomes; (6) cooperation with other providers; (7) patient participation; (8) effects; (9) culture and structure; (10) future. In the questionnaire, it was specifically asked, if the hospitals had ISO or HHCS certification. It was possible to fill out the survey within a half an hour. The questionnaire contained yes and no questions (does a certain activity exist), as well as multiple-choice questions of three answers of two types. In the first type, the possible answers were "no", "under development", “yes", in the second type "nonexistent”, “exists”, and "systematically" developed. The reliability and the validity of the questionnaire were described elsewhere [19] and [22].

\subsection{Analyses}

Quality has been measured replicating the method of previous studies on QMS, measuring the development stage of the QMS [19] and [22] (Table 1). In this study, we named the metric quality management system development score (QMSDS). The quality activities were grouped into five focal areas and four development levels, policy and strategy (Cronbach $\alpha$ 0.77), human resource management (Cronbach $\alpha$ 0.81), practice guidelines (Cronbach $\alpha$ 0.73 ), systematic quality improvement (Cronbach $\alpha 0.87$ ), and patient participation (Cronbach $\alpha$ 0.61).

\section{[TABLE 1]}

For the items in the first four focal areas, we used the affirmative answers (yes, this QMactivity is present in the organization). In the fifth focal areas, the items had three response options as follows: the quality improvement procedure: (1) is not present; (2) is present, but not entirely operational; (3) is present and operational. For the purposes of this article we combined the responses options 2 (present) and 3 (present and operational). 
Makai, P., Klazinga, N., Wagner, C., Boncz, I., Gulácsi, L. Quality management and patient safety: survey results from 102 Hungarian hospitals. Health Policy: 2009, 90(2-3), 175-180

For all dimensions separately, a score has been computed. Inside a given dimension, a hospital has reached a given level if it had all the quality activities of the level, and most of the activities of the previous levels. Then the average quality score of these dimensions was also computed [22]. These activities are assumed to be related to actual quality improvement [19].

Patient safety is measured through the number of patient safety activities. The following operational definition was used "The avoidance, prevention, amelioration of adverse outcomes or injuries stemming from the processes of healthcare. These events include "errors", "deviations" and "accidents" [18]". If an item met the definition, it was included in the analysis. The reliability coefficient for this scale was 0.79 (Cronbach $\alpha$ ).

All missing values were recorded as 0 , assuming that missing values implied that the QMS or safety activity was 'not present' in the organization. Hospitals with more than five missing quality, or activities were left out.

Subsequently, a relationship has been sought between the number of safety activities, the average QMS development stage of the hospitals (QMSDS), and if the hospital had ISO or HHCS certification.

To account for possible confounding factors, environmental variables have also been investigated, hospital size and region, and hospital type. Environmental variables are not included in the present analysis, since they were unrelated to all other measures. To establish all relationships, Pearson's correlation has been computed, and if it was significant on the $\mathrm{p}<0.05$ level, it has subsequently been included in a bivariate linear regression. The conditions for linear regression have been tested, and subsequently three have been performed: between the number of patient safety activities, and the QMDS, between the number of safety activities and ISO certification, and between the number of safety activities and HHCS certification.

\section{RESULTS}

\subsection{Response}

More then three-fourths of the hospitals have answered the questionnaire. The survey is most representative for the university hospitals, and least for the Budapest hospitals. However, there are no statistically significant differences in response by hospital type. Hospital size and region have also no significant effect on response (Table 2).

\section{[TABLE 2]}

\subsection{Quality management activities}

Based on these quality activities, the average hospital is in level 2 out of a total possible 3 levels (Table 1 and Table 3).

\section{[TABLE 3]}

\subsection{Certification}

Certification can be found in the majority of the hospitals, 81 (79\%) of the hospitals is ISO certified, 65 (63\%) has HHCS certification. A large number of hospitals $42(41 \%)$ have both certification systems in place.

\subsection{Patient safety activities}

The most common patient safety activities are adverse event reporting (90.3\%), and risk management (57.8\%). The least common activities are accident committees (10.7\%), and patient safety committees (24.3\%). In $84.4 \%$ of the hospitals, less then half of the investigated patient safety activities are carried out. The average number of patient safety activities is 4 out of 11 (37\%) (Table 4$)$. 
Makai, P., Klazinga, N., Wagner, C., Boncz, I., Gulácsi, L. Quality management and patient safety: survey results from 102 Hungarian hospitals. Health Policy: 2009, 90(2-3), 175-180

\section{[TABLE 4]}

\subsection{The relationship between the QMSDS and patient safety}

The QMSDS is weakly related to the number of patient safety activities (Pearson's correlation $=0.37$ ) (bivariate regression $\left.R^{2}=0.12\right)(p<0.000)$. The types of certification, ISO and HHCS, are not significantly related to the number of patient safety activities. There is a significant and weak relationship between the number of patient safety activities and the QMSDS. The QMSDS explains $12 \%$ of the total variance of the number of patient safety activities variable.

Thus although a positive relationship exists between the development of QMS's and patient safety activities, hospitals with a large number of patient safety activities rarely have a welldeveloped quality system and conversely, a hospital with a high level of quality does not automatically have a large number of patient safety activities as measured through our survey in Hungarian hospitals in 2005.

\section{DISCUSSION}

\subsection{Certification, quality management and safety}

This study was the first attempt to explore the relation between patient safety activities, quality management systems, and external certification in Hungary. According to our results, there is no significant relationship between ISO or HHCS certification and the number of patient safety activities. One explanation for the phenomenon may be that neither the Hungarian healthcare adaptation of the ISO, nor HHCS aims to directly improve patient safety. Furthermore, there is no clearly defined quality policy, therefore hospital-based quality activities may serve different quality and safety goals.

The QMSDS was only weakly but significantly related to the level of safety measured by the number of patient safety activities. Most of the variance between hospitals could not be explained with a well-developed QMS; therefore a well-developed quality system is not per se associated with more patient safety activities. This may be explained by the fact that welldeveloped QMS seem to be widespread. When compared to an earlier study, we find, that the average development level of the QMS is on a higher level in 2005, then in 2000 [22]. However, patient safety activities do not seem to be widespread in the Hungarian hospitals and are only developed to a limited extent as part of the existing quality policies.

On one hand, the existence of the relationship between quality and safety support the view, that patient safety should be integrated into quality management systems [24] and [25]. On the other hand, since the relationship is a fairly weak one, supports the approach taken by a number of countries that deal with patient safety as a separate policy [2] and [23].

\subsection{Limitations and strengths}

For this study, we used self-assessment questionnaires; therefore a positive bias is possible. In addition, self-selection may have occurred, when hospitals with less developed quality management systems have not returned the survey.

In addition, this study has not used outcome measures to evaluate quality and patient safety, since these are not available in Hungary. Instead we have used structure and process measures for both quality management activities, as well as for patient safety activities, which are though to be related to better outcomes. According to this line of reasoning, a hospital with a number of structural and process activities is more likely to have better outcomes, then a hospital that does not carry out these activities.

The strength of the study lies in the high response rate: $76 \%$ of all the Hungarian hospitals have returned the questionnaire, and that this high response did not vary significantly across hospital types. 
Makai, P., Klazinga, N., Wagner, C., Boncz, I., Gulácsi, L. Quality management and patient safety: survey results from 102 Hungarian hospitals. Health Policy: 2009, 90(2-3), 175-180

\section{CONCLUSIONS}

The first goal of this paper was to describe the level of QMS in Hungary, and the existing patient safety activities. All responding hospitals report to have established QMS by 2005, and the overwhelming majority of the hospitals are certified. In addition, a number of patient safety activities are present in the hospitals.

The second goal was to find a statistical relationship between the QMDS, certification, and the number of patient safety activities. Our results show that there is a significant relationship between the QMDS and the number of patient safety activities. There is no significant relationship between certification status and the number of patient safety activities.

The third goal of this paper was to explore if a separate patient safety policy is necessary in Hungary. According to our results the development of the quality management systems is not strongly related to patient safety. The hospital quality management strategy of the past decade does not guarantee a high level of patient safety. Results of our study highlight the importance of separate patient safety policies in Hungary. However, these should be in addition to the already established national quality management systems in Hungarian hospitals.

More research is needed to see whether the validity of our results are limited to the actual Hungarian health care system and quality management or generalizable to other countries, with particular emphasis on the new EU states. In these countries quality management systems have been introduced in a relatively short time, in a similar top-down fashion. And it seem of interest to find out how more focus on patient safety issues can be realized whilst further strengthening the only recently developed quality improvement infrastructure in hospitals.

\section{ACKNOWLEDGMENTS}

The authors would like to express special thanks to the European Commission and the Ministry of Health in Hungary and National Health Insurance Fund Administration Hungary, for their contribution.

\section{REFERENCES}

[1] S. Mattke, A.M. Epstein and S. Leatherman, The OECD health care quality indicators project: history and background, International Journal for Quality in Health Care 18 (2006), pp. $1-4$.

[2] L.T. Kohn, To err is human institute of medicine, National Academy Press, Washington, DC (2000).

[3] In: K. Adams and J.M. Corrigan, Editors, Priority areas for national action, National Academies Press, Washington, DC (2003).

[4] T.A. Brennan, L.L. Leape, N.M. Laird, L. Hebert, A.R. Localio and A.G. Lawthers et al., Incidence of adverse events and negligence in hospitalized patients. Results of the Harvard Medical Practice Study I, The New England Journal of Medicine 324 (6) (1991), pp. 370-377.

[5] R.M. Wilson, W.B. Runciman, R.W. Gibberd, B.T. Harrison, L. Newby and J.D. Hamilton, The quality in Australian Health Care Study, The Medical Journal of Australia 163 (9) (1995), pp. 458-476.

[6] E.J. Thomas, D.M. Studdert, W.B. Runciman, R.K. Webb, E.J. Sexton and R.M. Wilson et al., A comparison of iatrogenic injury studies in Australia and the USA. I. Context, methods, casemix, population, patient and hospital characteristics, International Journal for Quality in Health Care 12 (2000), pp. 371-378.

[7] C. Vincent, G. Neale and M. Woloshynowych, Adverse events in British hospitals: preliminary retrospective record review [published erratum in BMJ 2001;322:1395], BMJ 322 (7285) (2001), pp. 517-519.

[8] P. Davis, R. Lay-Yee, R. Briant, S. Schug, A. Scott and S. Johnson et al., Adverse events in New Zealand public hospitals: principal findings from a national survey, NZ Ministry of 
Makai, P., Klazinga, N., Wagner, C., Boncz, I., Gulácsi, L. Quality management and patient safety: survey results from 102 Hungarian hospitals. Health Policy: 2009, 90(2-3), 175-180

Health, Wellington (2001) Occasional Paper No. 3. Available:

www.moh.govt.nz/publications/adverseevents [accessed April 28, 2005].

[9] T. Schioler, H. Lipczak, B.L. Pedersen, T.S. Mogensen, K.B. Bech and A. Stockmarr et al., Danish Adverse Event Study. Incidence of adverse events in hospitals. A retrospective study of medical records, Ugeskr Laeger 163 (39) (2001), pp. 5370-5378. View Record in Scopus | Cited By in Scopus (75)

[10] G.R. Baker, P.G. Norton, V. Flintoft, R. Blais, A. Brown and J. Cox et al., The Canadian Adverse Events Study: the incidence of adverse events among hospital patients in Canada, Canadian Medical Association Journal 170 (11) (2004), pp. 1678-1686.

[11] P. Michel, J.L. Quenon, A.M. de Sarasqueta and O. Scemama, Comparison of three methods for estimating rates of adverse events and rates of preventable adverse events in acute care hospitals, BMJ 328 (2004), pp. 199-204.

[12] SIMPATIE. Mapping exercise: patient safety strategies in the EU; 2007. www.simpatie.org [accessed April 29, 2007].

[13] DELSA/ELSA/WD/HTP(2004)18OECD Technical Papers No. 18. Millar J, Mattke S, editors. Selecting indicators for patient safety at the health systems level in OECD countries; 2004, www.oecd.org/dataoecd/53/26/33878001.pdf accesed 24 okt 2008.

[14] K. Roberts, K. Yu and D. van Stralen, Patient safety is an organisational systems issue: lessons from a variety of industries. In: B.J. Youngberg and M.J. Hatlie, Editors, Handbook of patient safety, Jones and Bartlett, London (2004), pp. 169-188.

[15] C.E. Milch, D.N. Salem, S.G. Pauker, T.G. Lundquist, S. Kumar and J. Chen, Voluntary electronic reporting of medical errors and adverse events: an analysis of 92,547 reports from 26 acute care hospitals, Journal of General Internal Medicine 21 (February (2)) (2006), pp. 165-170.

[16] C. Vincente, Clinical risk management: enhancing patient safety, BMJ books, London (2001).

[17] C.D. Shaw, External quality mechanisms for health care: summary on the expert project on visitatie, accreditation, EFQM, and ISO assessment in European Union Countries, International Journal for Quality in Health Care 12 (2000), pp. 165-169.

[18] J.B. Cooper, D.M. Gaba, B. Liang, D. Woods and L.N. Blum, The National Patient Safety Foundation agenda for research and development in patient safety, MedGenMed 2 (3) (2000), p. E38. View Record in Scopus | Cited By in Scopus (8)

[19] C. Wagner, D.H. De Bakker and P. Groenewegen, A measuring instrument for evaluation of quality systems, International Journal for Quality in Health Care 11 (1999), pp. 119-130.

[20] E.M. Sluijs, M. Outinen, C. Wagner, M. Liukko and D. Bakker, The impact of legislative versus non-legislative quality policy in health care: a comparison between two countries, Health Policy 58 (2001), pp. 99-119.

[21] M. Hirose, Y. Imanaka, T. Ishizaki and E. Evans, How can we improve the quality of health care in Japan? Learning from JCQHC Hospital Accreditation, Health Policy 66 (2003), pp. 29-49.

[22] C. Wagner, L. Gulacsi, E. Takacs and M. Outinen, The implementation of quality management systems in hospitals: a comparison between three countries, BMC Health Services Research 6 (2006), p. 50.

[23] O.A. Arah and N.S. Klazinga, How safe is the safety paradigm?, Quality \& Safety in Health Care 13 (2004), pp. 226-232.

[24] A.D. Auerbach, C.S. Landefeld and K.G. Shojana, The tension between needing to improve care and knowing how to do it, The New England Journal of Medicine 357 (6) (2007), pp. 1405-1409.

[25] T.A. Brennan, A. Gawande, E. Thomas and D. Studdert, Accidental deaths, saved lives, and improved quality, The New England Journal of Medicine 353 (13) (2005), pp. 608-613.

[26] Gulacsi L. Hungarian healthcare in transition. Thesis, University of Amsterdam; 2001.

[27] N. Klazinga, Concerted action program on quality assurance in hospitals. 1990-1993 (COMAC/HSR/QA), global results of the evaluation, International Journal for Quality in Health Care 6 (1994), pp. 219-230. View Record in Scopus | Cited By in Scopus (8) Hungarian Act CLIV of 1997 on Health (1997 CLIV tv az Egészségügyröl) Hungarian Gazette 1997 (Magyar Közlöny). 
Makai, P., Klazinga, N., Wagner, C., Boncz, I., Gulácsi, L. Quality management and patient safety: survey results from 102 Hungarian hospitals. Health Policy: 2009, 90(2-3), 175-180

[28] Hungarian Hospital Care Standards Manual. http://www.eum.hu/index.php?akt_menu=2760.

[29] Guideline of Health Ministry about internal quality management system of health care providers and connected requirements (Az Egészségügyi Minisztérium szakmai irányelve az egészségügyi szolgáltatók belső minőségügyi rendszeréröl, azok követelményeiröl), Official Gazette of the Ministry of Health (Egészségügyi Közlöny); 2002.

[30] Treatment protocols of the Ministry of Health, http://agazat.eum.hu/eum/agazati.head.page?pid=DA_62161.

[31] Decree on patient identification 1/2005 Health Gazette (Egészségügyi miniszteri rendelet a betegazonosító rendzserről Egészségügyi közlöny). 
Makai, P., Klazinga, N., Wagner, C., Boncz, I., Gulácsi, L. Quality management and patient safety: survey results from 102 Hungarian hospitals. Health Policy: 2009, 90(2-3), 175-180

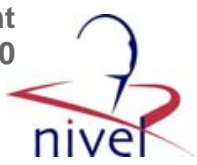

TABLES

Table 1: Quality development stages and focal areas.

\begin{tabular}{|c|c|c|c|c|c|}
\hline $\begin{array}{l}\text { Development } \\
\text { stage/qualit } \\
\text { y dimension }\end{array}$ & $\begin{array}{l}\text { Policy and } \\
\text { strategy }\end{array}$ & HRM & $\begin{array}{l}\text { Practice } \\
\text { guidelines } \\
\text { for }\end{array}$ & $\begin{array}{l}\text { Systematic quality } \\
\text { improvement }\end{array}$ & $\begin{array}{c}\text { Participation } \\
\text { of patients }\end{array}$ \\
\hline Stage 0 & $\begin{array}{l}\text { Mission } \\
\text { statement, } \\
\text { annual } \\
\text { quality } \\
\text { report }\end{array}$ & $\begin{array}{l}\text { Encouraging } \\
\text { professional } \\
\text { development }\end{array}$ & $\begin{array}{l}\text { Medical } \\
\text { treatment }\end{array}$ & Peer review, care plans & $\begin{array}{l}\text { Patient is not } \\
\text { involved }\end{array}$ \\
\hline Stage 1 & $\begin{array}{l}\text { Written } \\
\text { quality } \\
\text { policy } \\
\text { exists, } \\
\text { quality } \\
\text { action plan } \\
\text { under } \\
\text { developmen } \\
\text { t }\end{array}$ & $\begin{array}{l}\text { Training staff, } \\
\text { training } \\
\text { managers } \\
\text { QM-activities } \\
\text { within regular } \\
\text { working } \\
\text { hours, } \\
\text { management } \\
\text { explains } \\
\text { quality } \\
\text { requirements }\end{array}$ & $\begin{array}{l}\text { Patient } \\
\text { information } \\
\text {, medical } \\
\text { aids, } \\
\text { diagnostic } \\
\text { related } \\
\text { groups }\end{array}$ & $\begin{array}{l}\text { Complaints registration, } \\
\text { committees job } \\
\text { assessment interview }\end{array}$ & $\begin{array}{l}\text { Evaluating } \\
\text { quality goals }\end{array}$ \\
\hline Stage 2 & $\begin{array}{l}\text { Quality action } \\
\text { plan } \\
\text { developed }\end{array}$ & $\begin{array}{l}\text { New staff } \\
\text { selected on } \\
\text { quality } \\
\text { attitude, new } \\
\text { staff trained, } \\
\text { management } \\
\text { controls }\end{array}$ & $\begin{array}{l}\text { Critical } \\
\text { incidents, } \\
\text { cooperatio } \\
\mathrm{n} \text { with } \\
\text { other } \\
\text { providers }\end{array}$ & $\begin{array}{l}\text { Satisfaction research, } \\
\text { needs analysis, } \\
\text { management information } \\
\text { system, } \\
\text { certification/accreditation }\end{array}$ & $\begin{array}{l}\text { Development } \\
\text { of quality } \\
\text { criteria or } \\
\text { guidelines }\end{array}$ \\
\hline Stage 3 & $\begin{array}{l}\text { Quality action } \\
\text { plan and } \\
\text { quality } \\
\text { manual }\end{array}$ & $\begin{array}{l}\text { Training based } \\
\text { on quality } \\
\text { policy and } \\
\text { systematic } \\
\text { feedback }\end{array}$ & $\begin{array}{l}\text { Routing of } \\
\text { the patient } \\
\text { and critical } \\
\text { incidents }\end{array}$ & $\begin{array}{l}\text { Internal audit and } \\
\text { satisfaction research }\end{array}$ & $\begin{array}{l}\text { Committees } \\
\text { and } \\
\text { improvemen } \\
\text { t projects }\end{array}$ \\
\hline
\end{tabular}


Makai, P., Klazinga, N., Wagner, C., Boncz, I., Gulácsi, L. Quality management and patient safety: survey results from 102 Hungarian hospitals. Health Policy: 2009, 90(2-3), 175-180

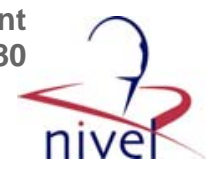

Table 2.: Response per hospital type.

\begin{tabular}{|l|l|}
\hline Hospital type & Response/total hospitals per type (\% of response) \\
\hline University hospitals & $4 / 4(100)$ \\
\hline National institutions & $7 / 10(70)$ \\
\hline County hospitals & $18 / 19(95)$ \\
\hline City hospitals & $43 / 58(74)$ \\
\hline Children's hospitals & $6 / 7(86)$ \\
\hline Specialty hospitals & $14 / 18(77)$ \\
\hline & \multicolumn{2}{|l}{} \\
\hline Total & $102 / 134(76)$ \\
\hline
\end{tabular}

Table 3: Quality activities.

\begin{tabular}{|c|c|}
\hline \multicolumn{2}{|l|}{ Quality policy documents } \\
\hline Mission statement & $68 \%$ \\
\hline Quality policy & $72 \%$ \\
\hline Quality action plan & $68 \%$ \\
\hline Annual quality report & $59 \%$ \\
\hline Quality manual & $64 \%$ \\
\hline \multicolumn{2}{|l|}{ Human resources management } \\
\hline Feedback to staff about results & $62 \%$ \\
\hline New staff selected on positive attitude & $42 \%$ \\
\hline Professionals trained in QM & $62 \%$ \\
\hline Management trained in QM & $60 \%$ \\
\hline Training based on quality policy & $30 \%$ \\
\hline QM activities within regular working hours & $73 \%$ \\
\hline New staff trained in QM & $35 \%$ \\
\hline Management explains quality requirements & $80 \%$ \\
\hline Management controls compliance with procedures & $70 \%$ \\
\hline
\end{tabular}


Makai, P., Klazinga, N., Wagner, C., Boncz, I., Gulácsi, L. Quality management and patient safety: survey results from 102 Hungarian hospitals. Health Policy: 2009, 90(2-3), 175-180

\begin{tabular}{|c|c|}
\hline Encouraging professional development & $77 \%$ \\
\hline \multicolumn{2}{|l|}{ Practice guidelines for } \\
\hline Medical treatment & $70 \%$ \\
\hline Patient information & $84.5 \%$ \\
\hline Medical aids & $21 \%$ \\
\hline Critical incidents & $51 \%$ \\
\hline Diagnostic related groups & $68 \%$ \\
\hline Routing of the patient & $64 \%$ \\
\hline Cooperation with other providers & $33 \%$ \\
\hline \multicolumn{2}{|l|}{ QI activities } \\
\hline Peer review & $70 \%$ \\
\hline Care plan management & $68 \%$ \\
\hline Job assessment interviews & $79 \%$ \\
\hline Internal audits & $69 \%$ \\
\hline Accreditation certification & $89 \%$ \\
\hline Management information system & $83 \%$ \\
\hline User satisfaction surveys & $96 \%$ \\
\hline Need surveys amongst users & $54 \%$ \\
\hline Complaints registration & $93 \%$ \\
\hline \multicolumn{2}{|l|}{ Patient participation } \\
\hline Evaluating quality goals & $13 \%$ \\
\hline Development of quality criteria & $5 \%$ \\
\hline Committees and improvement projects & $4 \%$ \\
\hline Development of guidelines & $3 \%$ \\
\hline Average number of $\mathrm{Ql}$ activities & 24.5/35 (S.D. 6.4$)$ \\
\hline
\end{tabular}


Makai, P., Klazinga, N., Wagner, C., Boncz, I., Gulácsi, L. Quality management and patient safety: survey results from 102 Hungarian hospitals. Health Policy: 2009, 90(2-3), 175-180

Table 4.:Patient safety and related activities in the Hungarian hospitals.

\begin{tabular}{|l|l|}
\hline Patient safety activities & $\begin{array}{l}\text { \% of hospitals with activity } \\
\text { present }\end{array}$ \\
\hline Adverse event reporting system & $90.3 \%$ \\
\hline Patient safety committee & $24.3 \%$ \\
\hline Risk management & $57.8 \%$ \\
\hline Accidents committee & $10.7 \%$ \\
\hline Commitment of management & $43.7 \%$ \\
\hline Patient safety training & $65.0 \%$ \\
\hline Delineation of recourses & $10.7 \%$ \\
\hline Usage of adverse event reporting system & $39.8 \%$ \\
\hline Prevention of falls & $19.4 \%$ \\
\hline Prevention of medication (administration) errors & $55.3 \%$ \\
\hline Reporting (near) accidents & $31.1 \%$ \\
\hline & \multicolumn{2}{|l|}{} \\
\hline Average number of patient safety activities per & 4.6 (out of 11) (S.D. 2.2) \\
\hline hospital & \multicolumn{2}{|l|}{$\mid$} \\
\hline
\end{tabular}

